\title{
Insurance Policy Purchase Decision in Surabaya, Indonesia
}

\author{
Sesilya Kempa ${ }^{1 *}$, Wiliam Ardiyanto Wisnu Pratama ${ }^{1}$, and \\ Noneng Rokayah Sukatmadiredja ${ }^{2}$ \\ ${ }^{1}$ Faculty of Business and Economics, Petra Christian University, Siwalankerto 121-131, \\ Surabaya 60236, Indonesia. \\ ${ }^{2}$ University Pendidikan Sutan Idris, Tanjong Malim, Perak Darul Ridzuan 35900, Malaysia
}

\begin{abstract}
The level of competition in the insurance world that is getting tougher makes the insurance business do a lot of strategies, both promotion, service, and others. Consumer decisions in buying insurance policies themselves are influenced by several things. This study emphasizes the presence of the influence between company reputation and product knowledge on purchase decisions as well as the influence of both variables through consumer trust of insurance policies from insurance companies in Surabaya. The data collection is carried out on 130 consumers who have bought an insurance policy. From 130 questionnaires returned, there are only 100 questionnaires which can then be further processed using Partial Least Square 2.0 analysis. The results of data processing show that company reputation, product knowledge, and consumer trust influence the purchase decisions respectively of 0.204 , 0.203 , and 0.494 . While the influence of company reputation and product knowledge on customer trust are 0.452 and 0.471 , respectively. Customer trust itself is proven to be an intervening variable between company reputation and product knowledge and on purchase decision making.
\end{abstract}

Keywords: Company reputation, consumer trust, insurance buying decision, product knowledge.

\section{Introduction}

One way to overcome the complicated expenses due to risk or uncertainty of an illness is to buy an insurance policy from a reputable insurance company. Coverage provided by a private insurance company can transfer risk, or what is commonly referred to as risk transferring, from the insured or the customer to the guarantor or the insurance company. Generally, insurance has two types of products namely life insurance and health insurance. Indonesia has many individual insurance companies running that focus on life insurance, health insurance, education insurance, and other insurance, for example PT Prudential Life Assurance, PT Asuransi Jiwa Manulife Indonesia, PT Asuransi Jiwa Sinarmas MSIG, PT Asuransi Jiwa sraya, PT AIA Financial, PT Asuransi Allianz Life Indonesia, PT Axa Financial Indonesia, and others.

\footnotetext{
${ }^{*}$ Corresponding author: sesilya.kempa@petra.ac.id
} 
Calvin and Semuel say that insurance is a system in which financial protection or financial loss for life, property, health, etc. gets reimbursed from unexpected events as death, loss, damage, which involves regular premium payments over a period of time as a policy guaranteeing the protection [1].

The growth of insurance business in Indonesia's market share is driven by the economic expansion and liquidity in the financial system, thus the number of people applying for insurance policies tends to move along with economic growth. The growth of the insurance industry relies on the increasing number of middle-income residents [2]. The decision to purchase an insurance policy is influenced by many things. Hasyim and Helmi's research shows that the purchase decision depends on the consumer trust which is influenced by perceived of usefulness and company reputation [3]. Company reputation becomes a benchmark for both companies in the eyes of the public or their consumers.

Stanislaus and Pratiwi's research shows that there is a positive impact between product knowledge and purchase decision [4]. Product knowledge from any insurance marketers must show an explanation of everything about what the marketer offers, and must be clear and concised as being used as a consideration for consumers in making purchasing decisions. Consumer trust is an important key in making consumer purchasing decisions because the higher the level of trust, the more confident consumers are able in making purchases. Insurance policy purchasing decisions often meet with unique things. Prospective customers who have been met and prospected by marketers often show positive gestures, but in the end they will not be buying for a various of reasons. Selling insurance in Surabaya in 2017 reached $2.87 \times 10^{6}$ people with an estimated number of 783394 households with an average of around three or four people per household [5].

The Indonesian General Insurance Association of East Java noted that insurance growth in 2016 in East Java increases by $10 \%$, compared to 2015 which only increases by $5 \%$ to $6 \%$. The city of Surabaya as the second largest city in Indonesia makes it interesting to study, whether the penetration of insurance companies in the city of Surabaya is already maximum or not.

\section{Theoretical review}

\subsection{Insurance}

Jessica, Barnett, and Marina define health insurance as managing one's health costs [6]. Hartono [in 7] argues that insurance is a risk transfer tool, meaning that it can be used as a vehicle for risk transfer. The risk of one party (the insured) is transferred to another party (the guarantor). Transition can be by agreement. The only agreement that allows insurance agreements or dependency agreements, which can be positioned as insured items can be an individual, a group of people, an institution, or even the wider community. Whereas, those who can be assumed as the position of the guarantor are insurance companies as institutions.

\subsection{Purchase decision}

Kotler and Keller define purchase decisions as how consumers make alternative choices to choose, and include decisions about what is bought, whether to buy or not, when to buy, where to buy, and how to pay for it, on at this stage the consumer has actually bought a product [8]. Alternative choices must be available to someone when making a decision. The purchasing decision is an individual's direct involvement in choosing between alternative options. Sometimes in taking these purchasing decisions, there are other parties who 
influence the individual, so it needs to be reconsidered and the decision can change from the original decision [8].

\subsection{Company reputation}

Company reputation from the insurance company itself is the reason which makes the community or prospective customers determine to buy, or even not to buy at all. Fombrun and Riel [in 9] fine company reputation as an overall organizational assessment by stakeholders while according to Robert and Dowling [in 9] say that company reputation is a perceptual representation from the company's past actions and prospects of the company in the future, which illustrates the overall appeal of the company to all constituents when compared to its main competitors.

\subsection{Product knowledge}

Lin [in 10] said product knowledge is the perception or knowledge consumers have of a particular product, including prior experience when using the product. Waluyo and Pamungkas [in 11] said that product knowledge is the scope of all accurate information stored in consumer memory as well as the perception of product knowledge. Consumer product knowledge greatly influences the purchase decision of a product/service, but what will be discussed in this research is product knowledge from insurance company marketers. Nugroho said product knowledge is an important thing that must be communicated by marketers in providing instructions for the products they offer to consumers [12].

\subsection{Consumer trust}

Schiffman and Joseph define trusting as confidence in the institution's leadership and vision [13]. Sangadji and Sopiah conclude that consumer trust is the power of knowledge possessed by consumers and all conclusions consumers make that products have objects, attributes and benefits [14]. Trust is the foundation of business, a business transaction between two or more parties will occur if each trusts each other [15]. Consumer trust is a belief from one party regarding the intent and behavior directed to the other party, thus consumer trust is defined as a consumer's expectation that the service provider can be trusted or relied upon to fulfill its promises [16]. According to Kotler and Keller, trust is the willingness of companies to depend on business partners [8]. Trust depends on several interpersonal and interorganizational factors such as competence, integrity, honesty and kindness.

\subsection{The relationship between concepts and research hypotheses}

\subsubsection{The effect of company reputation on purchase decision}

Reputation in marketing science can be interpreted as a link between companies formed individually with the name of the company [17]. In a study conducted by Pradipta, Farida and Nugraha, it was shown that there is a significant positive influence on company reputation with a decision decision [18]. The research is also supported by Tarigan's research which shows the reputation of the company having a positive effect on purchasing decisions [19]. Explained further by Rosidah, the company reputation in the eyes of consumers acts as a perception that illustrates the company's ability to provide the best service for its consumers [20]. The best service in this case is oriented as the company's 
ability to satisfy and meet all the needs and expectations of consumers. Companies with a positive reputation in providing services to consumers, consumers will have satisfaction that will affect the decision to purchase products or services.

Well maintained company reputation by focusing on the business it does will make the company specialize in business that is more visible to consumers [21]. A good company reputation will also increase the company's credibility in the eyes of its customers so that consumers will have a high level of trust in the company, and this reputation can be associated as a guarantee that consumers will get what they want [17]. Based on the description, the research hypothesis can be arranged as follows:

$\mathrm{H}_{1}$ : Company reputation has a positive influence on purchase decision.

\subsubsection{The effect of company reputation on consumer trusts}

Rahmawati writes that the good reputation of a company in providing services can be influenced by several things, one of which is the experience of consumers in feeling the service in the past [22]. In a study conducted by Rahmawati, it proves that there is a positive influence on the relationship between company reputation and consumer trust [22]. It is further explained that trust can occur due to a process based on consumer experience in using a product or service. A company with a good reputation and continously willing to develop its services to consumers will gain higher consumer confidence because the company has the intention to continue to provide all the needs and expectations of its customers. Based on the above description, the research hypothesis can be arranged as follows:

$\mathrm{H}_{2}$ : Company reputation has a positive influence on consumer trust.

\subsubsection{The effect of product knowledge on purchase decision}

Product knowledge is always related to consumer behavior that is influenced by the activity of gathering information related to a product [23]. A purchasing decision consists of several stages, starting from the need recognition, information search, alternative evaluations, purchasing decisions, to evaluation after purchase. From the related theoretical reviews on product knowledge and purchasing decisions, it can be concluded that a product knowledge will also influence the purchase decision. Consumers will try to collect information to sharpen their knowledge of a product they want to buy so that important information is obtained before making a product purchase process. This is in accordance with the theory conveyed by [24] hat a purchase decision will be based on the information about the advantages of a product that are arranged in such a way to cause a sense of pleasure that will drive someone to make a purchase decision. Product knowledge that has an important contribution to consumers in making purchasing decisions is influenced by four activities, namely advertising, the credibility of marketers, reference groups and the existence of public relations activities.

In a study conducted by Stanislaus and Pratiwi, product knowledge has a positive effect on purchase decisions [4]. The product knowledge has an important role in the buying behavior of a product. In this condition, the consumer must first know the characteristics of a product. The more consumers understand the characteristics of a product, the decision to purchase products by consumers will be more rational. Meanwhile, if consumers' understanding of the product is getting less then consumers can make the wrong buying decision [25]. The existence of psychological product knowledge will show the point of view of consumers openly so that consumer knowledge of a product will be able to help consumers to make their decisions effectively, including decisions in purchasing. Based on the above description, the research hypothesis can be arranged as follows:

$\mathrm{H}_{3}$ : Product knowledge has a positive influence on purchase decision. 


\subsubsection{The effect of product knowledge on consumer trust}

Knowledge possessed by the community has a quite central role in the business world. On the side, a knowledgable consumer will give effects to the trust in a product or brand. On the marketing side, the trust shown by consumers is very necessary so that the products they market are able to be widely accepted by consumers [26]. The results of research conducted by Wang, Chen, and Jiang state that there are many factors influencing consumer confidence, of which one of the strongest is product knowledge [27]. This can be explained that the level of consumer knowledge on a product or service increases, the level of overall consumer confidence will also increase. In the long-term, the bonds between product knowledge and trust will enable the company to evaluate and provide better services to meet all the needs of its consumers. In such cases, it will be very possible for companies to continue to encourage consumer knowledge of their products by optimizing the level of trust that consumers have based on consumer knowledge about the profile, products and services of the company [26]. Based on the description, the research hypothesis can be arranged as follows:

H4: Product knowledge has a positive effect on consumer trust.

\subsubsection{The effect of consumer trust on purchase decisions}

In a buying and selling relationship, the buyer and the seller will develop a level of trust among each other. On one hand, the seller must trust his customers so that consumers are willing to make a purchase. While on the consumer side, the trust is shown to the seller by consumers through the confident that the seller is able to provide the goods and services needed by consumers [28]. When both parties trust each other, then both will try to keep their promises made during the beginning of the relationship. Satrio, Lindawati and Kamener (2015) state that the decision making process of consumers will occur after consumers search and process information, which is the next step of addressing the information they receive [29]. Consumer attitude is an important factor that will influence consumers' decisions on information about a product. The concept of attitude is related to the concepts of trust and behavior. Consumers usually have confidence in the attributes of a product which is an inherent image in the product. Kusumawardani reveals that one of the obstacles causing consumers not to make purchases is the level of consumer confidence [30]. From this review it can be concluded that there is a relationship between the consumer trust with the consumer's decision to buy a product or service. If consumers have a good level of trust in producers, the tendency to make purchases will also be higher. While if the level of consumer confidence in producers is less, the tendency to make purchases will also be lower. Based on the description, the research hypothesis can be arranged as follows: H5: Consumer trust has a positive influence on the decision decision.

\subsubsection{The effect of company reputation and product knowledge on purchase decisions through consumer trust}

Consumer trust as a variable that mediates the influence between company reputation and product knowledge on purchase decisions will be discussed in the following research. Several previous studies have put consumer trust as an intervening variable. A research conducted by Rosidah state that consumer trust has a positive and significant influence in mediating the relationship between advertising on fresh product purchasing decisions at Carrefour Rungkut Surabaya [31]. A research conducted by Simamora and Celeste also states that there is a positive and significant influence between company reputation on purchasing decisions through consumer trust [21]. Based on the studies above, that the consumer trust is able to interfere its relationship with independent and dependent 
variables, this study wants to re-examine consumer trust as the intervening variable that influences the company reputation and the product knowledge on the purchase decisions of buying insurance policies. Based on the description, the research hypothesis can be arranged as follows:

$\mathrm{H}_{6}$ : Consumer trust has a positive effect as a variable intervening company reputation for purchase decisions.

$\mathrm{H}_{7}$ : Consumer trust has a positive effect as a variable intervening product knowledge on purchase decisions.

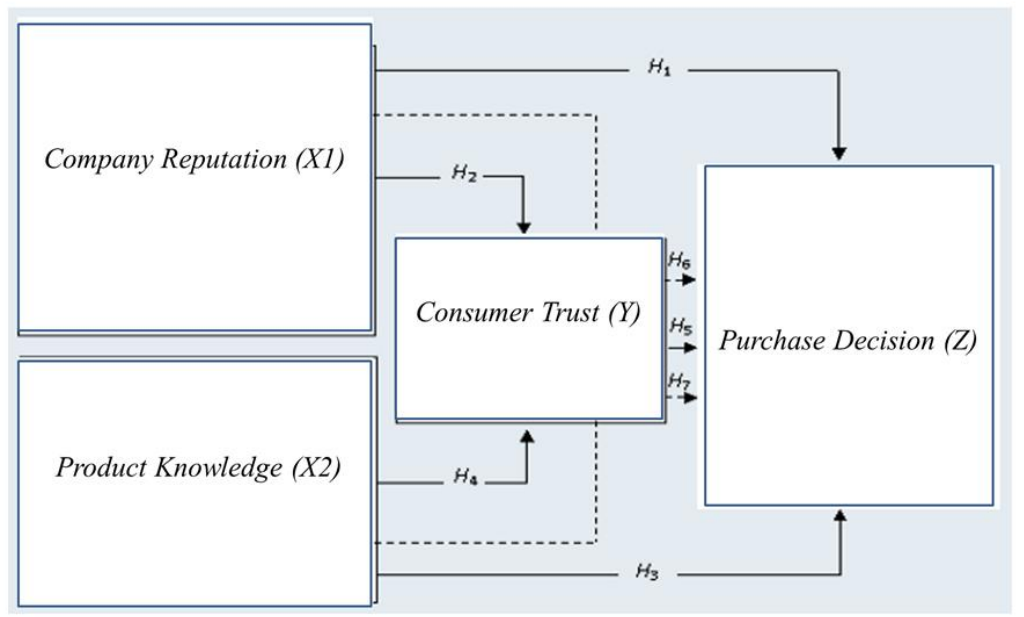

Fig. 1. Research framework

\section{Research method}

This research belongs to a quantitative research method. The type of research is a causality research to show the direction of the influences that exists among variables. The purpose of this study is to determine the influence of company reputation and product knowledge on purchase decisions through consumer trust in buying insurance policy in Surabaya. The population for this study is Surabaya citizen, age from $15 \mathrm{yr}$ to $65 \mathrm{yr}$ who have bought an insurance policy at least once. The sample is drawn as many as 100 respondents. Data collection is using a questionnaire, which is constructed with a Likert scale of five levels from strongly disagree to strongly agree.

This study uses a partial regression analysis technique (Partial Least Square/PLS) to test all proposed research hypotheses. Each of these hypotheses will be analyzed using the SmartPLS 2.0 application to test the effect between variables using the following stages $[32,33]$.

\section{Result}

\subsection{The analysis of partial least square}

Before testing the hypothesis with the PLS software, there are several requirements. 


\subsection{Evaluation of the outer model}

In the outer model, the convergent validity and discriment validity tests are performed. To test the reliability of the construct, the composite capability is performed. The results of each test are explained below.

\subsubsection{Convergent validity}

Testing the convergent validity is done by seeing the outer loading value and the average variance extracted (AVE) value. An indicator is said to meet convergent validity if it has an outer loading value and average variance extracted (AVE) is higher than 0.5. Table 1. shows the result of the outer loading value and the AVE.

Table 1. The Outer Loading Value and AVE

\begin{tabular}{|c|c|c|c|c|}
\hline Variable & Indicator & $\begin{array}{c}\text { Outer } \\
\text { Loading }\end{array}$ & $\begin{array}{l}\text { Average Variance } \\
\text { Extracted (AVE) }\end{array}$ & Remarks \\
\hline \multirow{19}{*}{ Company Reputation } & $\mathrm{X} 1.1 .1$ & 0.813 & \multirow{19}{*}{0.502} & \multirow{20}{*}{ Valid } \\
\hline & $\mathrm{X} 1.1 .2$ & 0.868 & & \\
\hline & X1.1.3 & 0.844 & & \\
\hline & $\mathrm{X} 1.2 .1$ & 0.840 & & \\
\hline & $\mathrm{X} 1.2 .2$ & 0.734 & & \\
\hline & $\mathrm{X} 1.2 .3$ & 0.803 & & \\
\hline & $\mathrm{X} 1.2 .4$ & 0.797 & & \\
\hline & $\mathrm{X} 1.3 .1$ & 0.817 & & \\
\hline & $\mathrm{X} 1.3 .2$ & 0.903 & & \\
\hline & $\mathrm{X} 1.3 .3$ & 0.850 & & \\
\hline & X1.4.1 & 0.826 & & \\
\hline & $\mathrm{X} 1.4 .2$ & 0.846 & & \\
\hline & $\mathrm{X} 1.4 .3$ & 0.821 & & \\
\hline & X1.5.1 & 0.827 & & \\
\hline & $\mathrm{X} 1.5 .2$ & 0.904 & & \\
\hline & $\mathrm{X} 1.5 .3$ & 0.891 & & \\
\hline & $\mathrm{X} 1.5 .4$ & 0.781 & & \\
\hline & $\mathrm{X} 1.6 .1$ & 0.861 & & \\
\hline & X1.6.2 & 0.881 & & \\
\hline \multirow{5}{*}{ Product Knowledge } & $\mathrm{X} 1.6 .3$ & 0.711 & \multirow{5}{*}{0.570} & \\
\hline & $\mathrm{X} 2.1$ & 0.755 & & \multirow{4}{*}{ Valid } \\
\hline & X2.2 & 0.708 & & \\
\hline & $\mathrm{X} 2.3$ & 0.690 & & \\
\hline & $\mathrm{X} 2.4$ & 0.857 & & \\
\hline \multirow{6}{*}{ Consumer Trust } & Z1.1 & 0.764 & \multirow{6}{*}{0.550} & \multirow{6}{*}{ Valid } \\
\hline & $\mathrm{Z} 2.1$ & 0.794 & & \\
\hline & $\mathrm{Z} 2.2$ & 0.807 & & \\
\hline & $\mathrm{Z} 3.1$ & 0.711 & & \\
\hline & $\mathrm{Z} 3.2$ & 0.650 & & \\
\hline & $\mathrm{Z} 3.3$ & 0.711 & & \\
\hline \multirow{5}{*}{ Purchase Decision } & $\mathrm{Y} 1$ & 0.794 & \multirow{5}{*}{0.698} & \multirow{5}{*}{ Valid } \\
\hline & $\mathrm{Y} 2$ & 0.854 & & \\
\hline & Y3 & 0.843 & & \\
\hline & Y4 & 0.885 & & \\
\hline & Y5 & 0.797 & & \\
\hline
\end{tabular}

Based on Table 1, all of the outer loading value and the value of the average variance extracted (AVE) have the value greater than 0.5 , so it can be concluded all indicators have fulfilled the convergent validity. 


\subsubsection{Discriminant validity}

Discriminant validity testing is done by looking at the value of cross loading, ini which each indicator has the largest value compared to the cross loading value on the variables. After comparing the cross loading values of every indicator, it can be said that all indicators have fullfiled the requirements as the discriminant validity.

\subsubsection{Composite reliability}

A variable is said to meet the construct reliability if it has a Cronbach alpha value higher than 0.6 , and the composite reliability of higher than 0.7 . Table 2 summarizes the value of Cronbach Alpha and the composite reliability.

Table 2. The value of Cronbach Alpha and the Composite Reliability

\begin{tabular}{lcc}
\hline \multicolumn{1}{c}{ Variables } & $\begin{array}{c}\text { Cronbach } \\
\text { Alpha }\end{array}$ & $\begin{array}{c}\text { Composite } \\
\text { Reliability }\end{array}$ \\
\hline Company Reputation & 0.947 & 0.952 \\
Product Knowledge & 0.746 & 0.841 \\
Consumer Trust & 0.836 & 0.879 \\
Purchase Decision & 0.891 & 0.920 \\
\hline
\end{tabular}

\subsection{Evaluation of the inner model}

The inner model will explain the R-Square results and test the hypothesis.

\subsubsection{R-Square}

Based on data processing with PLS, the resulting R-Square values are as follows:

Table 3. The Value of R-Square

\begin{tabular}{ll}
\hline Endogen variable & R-Square \\
\hline ConsumerTrust & 0.706 \\
Purchase Decision & 0.688 \\
\hline
\end{tabular}

Table 3. shows the values of R-Square for the variable of consumer trust of 0.706 , which means the percentage of respondent perception on customer traust can be explained with the variables of company reputation and product knowledge as high as $70.6 \%$. Meanwhile, the value of R-Square for the variable of purchase decision is 0.688 , which means the percentage of respondent on purchase decision can be explained with the variables of company reputation and product knowledge as high as $68.8 \%$.

\subsection{Hypothesis testing}

Hypothesis testing is done by looking at the value of the coefficient of influence and pvalues generated from the inner model on PLS. The hypothesis can be accepted if the effect coefficient is positive and the value of T-Statstics is higher than 1.96.

Table 4 reveals the coeficient values of the direct effect and the T-Statistics which are obtained from the inner model. 
Table 4. Hypothesis Testing of Direct Effect

\begin{tabular}{llcc}
\hline Hypothesis & Coefficient & T-Statistics \\
\hline $\mathrm{H}_{1}$ & Company Reputation $\rightarrow$ Purchase Decision & 0.204 & 2.336 \\
$\mathrm{H}_{2}$ & Company Reputation $\rightarrow$ Consumer Trust & 0.452 & 5.960 \\
$\mathrm{H}_{3} \quad$ Product Knowledge $\rightarrow$ Purchase Decision & 0.203 & 2.069 \\
$\mathrm{H}_{4} \quad$ Product Knowledge $\rightarrow$ Consumer Trust & 0.471 & 6.302 \\
$\mathrm{H}_{5} \quad$ Consumer Trust $\rightarrow$ Purchase Decision & 0.494 & 4.525 \\
\hline
\end{tabular}

From the result of the estimated PLS structural model, this research can calculate the value of the indirect effect of the company reputation variable and the product knowledge variable to the purchase decision variable through the consumer trust variable. Table 5. reveals the coeficient values of the indirect effect which is obtained from the inner model.

Table 5. Hypothesis Testing of Indirect Effect

\begin{tabular}{llcc}
\hline \multicolumn{1}{c}{ Path } & $\begin{array}{c}\text { Direct } \\
\text { Effect }\end{array}$ & Indirect Effect \\
\hline $\mathrm{H}_{6}$ & $\begin{array}{l}\text { Company Reputation } \rightarrow \text { Consumer Trust } \rightarrow \text { Purchase } \\
\text { Decision }\end{array}$ & 0.204 & $0.452 \times 0.494=0.223$ \\
$\mathrm{H}_{7}$ & $\begin{array}{l}\text { Product Knowledge } \rightarrow \text { Consumer Trust } \rightarrow \text { Purchase } \\
\text { Decision }\end{array}$ & 0.203 & $0.471 \times 0.494=0.233$ \\
\hline
\end{tabular}

\subsubsection{Hypothesis 1}

Based on Table 2, it is shown that the direct effect coefficient between the company reputation and the purchase decision is 0.204 with the T-Statistics value of 2.336 . The result of the T-Statistics value of 2.336 indicates a value greater than 1.96 , so it can be concluded that there is a positive influence between the company reputation and the purchase decision for insurance customers in Surabaya. The result suggests that the $\mathrm{H}_{1}$ is accepted as it is statistically proven.

The result of data analysis for the company reputation and purchase decision shows a coefficient of 0.204 , which has a positive direction. This also means if the insurance company reputation is getting better, the purchase decisions from customers will also be higher.

The influence between company reputation and the purchase decision is concluded significant, it is similar to the research of Simamora and Celeste, which concludes the company reputation by means of focusing on doing business will make the company's expertise and credibility to increasingly visible to consumers and in the end will generate a trust [21]. Descriptive results indicate that the customers decided to invest in insurance companies because of the information that is relevant for meeting the needs of customers. This is reinforced that insurance companies have been seen as being able to meet and support the goals and expectations of customers.

\subsubsection{Hypothesis 2}

Table 2 shows the coefficient of direct effect between the company reputation and consumer trust of 0.452 , with the T-statistics of 5.960. As the value of the T-statistics is higher than 1.96, it can be concluded that there is a positive influence between the company reputation and the consumer trust among the consumer of insurance companies in Surabaya. The result suggests that the $\mathrm{H}_{2}$ is accepted as it is statistically proven.

The result of data analysis for the company reputation and consumer trust shows a coefficient of 0.452 , which has a positive direction. This also means if the insurance company reputation is getting better, the consumer trust from customers will also be higher. 
The influence between company reputation on consumer trust is concluded as significant and in accordance to Rahmawati's research, which suggests there is a positive influence on the relationship between company reputation and consumer trust [22]. Consumer trust can be realized because of the existence of a process based on consumer experience in using a product or service. A company with a good reputation and always trying to develop services to consumers will have a higher consumer trust because the company has the intention to continue to provide all the needs and expectations of its customers. The descriptive results show that customer trust occurs due to the truth of information obtained, one of which is due to the responsibility and the customer's admiration for the services provided by insurance companies.

\subsubsection{Hypothesis 3}

The direct effect coefficient between the product knowledge and purchase decision is 0.203 , with the T-statistics of 2.069. As the T-statistics is higher than 1.96 , it can be concluded that there is a positive influence between product knowledge and purchase decision from all consumer of insurance companies in Surabaya. The result suggests that the $\mathrm{H} 3$ is accepted as it is statistically proven.

The result of data analysis for the product knowledge and purchase decision shows a coefficient of 0.203 , which has a positive direction. This also means if the product knowledge given by insurance companies is getting better, the purchase decisions from customers will also be higher.

The influence of product knowledge on purchase decision is concluded to be significant, which is in accordance with Stanislaus and Pratiwi's conclusion that product knowledge has a positive influence on purchase decisions. Product knowledge plays a role that can be utilized by consumers in determining behavior in purchasing [4]. Consumer understanding of product attributes provided and explained by the product or service providers will also determine consumer behavior. If consumers understand the characteristics of the products, the decision to purchase products made will be more rational. In the results of descriptive analysis, it is mentioned that the understanding possessed by marketers (agents) on the product attributes of insurance is good so that it can be a guideline for customers in making purchases because the product information provided to them is already relevant to the conditions.

\subsubsection{Hypothesis 4}

Based on Table 2, it is shown that the direct effect coefficient between the product knowledge and the consumer trust is 0.471 with the T-Statistics value of 6.302 . The result of the T-Statistics value of 6.302 indicates a value greater than 1.96 , so it can be concluded that there is a positive influence between the product knowledge and the consumer trust for insurance customers in Surabaya. The result suggests that the H4 is accepted as it is statistically proven.

The result of data analysis for the product knowledge and consumer trust shows a coefficient of 0.471 , which has a positive direction. This also means if the product knowledge is getting better, the consumer trust from customers will also be higher.

The influence of the product knowledge on consumer trust is concluded to be significant and in accordance with a research by Wang, Chen, and Jiang [27] which states that one of the strongest and influencial consumer confidence in a product or service is knowledge. If the level of consumer knowledge on a product or service is increasing, the level of consumer trust as a whole will also increase. The descriptive results show the knowledge of the customers on the function of the insurance products is perceived as good, in which this will give benefits to the personal self of the customer and also the insurance provider. 


\subsubsection{Hypothesis 5}

The direct effect coefficient between the consumer trust and purchase decision is 0.494 , with the T-statistics of 4.525. As the T-statistics is higher than 1.96, it can be concluded that there is a positive influence between consumer trust and purchase decision from all consumer of insurance companies in Surabaya. The result suggests that the $\mathrm{H}_{5}$ is accepted as it is statistically proven.

The result of data analysis for the consumer trust and purchase decision shows a coefficient of 0.204 , which has a positive direction. This also means if the insurance company reputation is getting better, the consumer trust from customers will also be higher.

The influence of consumer trust on purchase decisions is concluded to have a positive impact, which is in accordance with research by Satrio, Lindawati and Kamener explaining that purchase decisions will be made by consumers if the consumers carry out information searches and processes, and respond to the information provided [29]. The attitude shown by consumers can be related to the concept of trust and behavior, so the existing trust in consumers will determine the level of product purchase. Consumers usually have confidence in the attributes of a product which features the inherent image of the product. This reinforces that the insurance company must have an image to always keep promises to its consumers so this will increase the level of consumer trust that the consumer makes a purchase because the information obtained has been appropriate and the promises are well kept by the company.

\subsubsection{Hypothesis 6}

The results in Table 5 show that the value of the indirect effect path of the company reputation to the purchase decision through the consumer trust as an intervening variable is 0.223 , which the value is greater than the direct effect between the company reputation and the purchase decision of 0.204 . Thus it can be concluded that the consumer trust can act as an intervening variable from the company reputation to the purchase decisions. The result suggests that the $\mathrm{H}_{6}$ is accepted as it is statistically proven.

\subsubsection{Hypothesis 7}

The results in Table 5 also show that the value of the indirect effect path of the product knowledge to the purchase decision through the consumer trust as an intervening variable is 0.233 , which the value is greater than the direct effect between the company reputation and the purchase decision of 0.203 . Thus it can be concluded that the consumer trust can play as an intervening variable from the product knowledge to the purchase decisions. The result suggests that the $\mathrm{H}_{7}$ is accepted as it is statistically proven.

As an intervening variable, consumer trust is concluded to have a positive influence, which is in accordance with a research conducted by Rosidah stating consumer trust having a positive and significant influence in mediating the influence between advertising and purchase decision in buying fresh products [31]. A research conducted by Simamora and Celeste also state that there is a positive and significant effect between company reputation on purchasing decisions through consumer trust, thus it can be concluded that consumer trust can increase the decision-making of the customers [23]. 


\section{Conclusion}

The decision to purchase an insurance policy is influenced by the reputation of the company and the product knowledge. The good company reputation and product knowledge will influence consumer trust in purchasing insurance products in Surabaya. The higher level of consumer trust can increase the consumer's decision to make a purchase because with a sense of trust, it becomes easier for customers to decide on the purchase. In the future, this research can be replicated into a bigger sample sizes from different big cities in Indonesia.

\section{References}

1. C. Tandun, Jurnal Manajemen Pemasaran Petra, 2,1:1-11(2014). [in Bahasa Indonesia]. http://publication.petra.ac.id/index.php/manajemenpemasaran/article/view/1999

2. Investor Daily. Pasar Asuransi Menggiurkan [Seductive Insurance Market]. [Online] from https://id.beritasatu.com/home/pasar-asuransi-menggiurkan/64120 (2013).

3. A. Hasyim, Helmi, Journal of Economics, Commerce and Management, 5,2:329343(2017). https://digilib.esaunggul.ac.id/UEU-Journal-11_0044/13075

4. S. Stanislaus, P.E. Pratiwi, Jurnal Psikologi Ilmiah, 4,2:1-5(2012). [in Bahasa Indonesia].https://lib.unnes.ac.id/14115/

5. M. Alamsyah, Statistik daerah kota Surabaya 2018. [Statistics of the city of Surabaya 2018]. Surabaya: Badan Pusat Statistik Kota Surabaya. http://dpmptsp.surabaya.go.id/v3/po-content/po-upload/pdrb-2010-2016/Statistik-DaerahKota-Surabaya-2018-r.pdf [in Bahasa Indonesia].

6. J.C. Barnett, M.S. Vornovitsky, Health insurance coverage in the United States: 2015, Washington, DC: U.S. Government Printing Office (2016). https://www.khi.org/assets/uploads/news/14561/p60-257.pdf

7. M.A. Wikantari, Asuransi jiwa: Teori dan tantangan perusahaan asuransi jiwa di Indonesia, [Life insurance: Theories and challenges of life insurance companies in Indonesia], [Research paper], p. 1-49 (2014). [in Bahasa Indonesia]. https://www.researchgate.net/publication/326224618_Asuransi_Jiwa_Kajian_Teor i

8. P. Kotler, K.L. Keller. Marketing Management, London: Pearson (2016). http://www.gbv.de/dms/zbw/825939119.pdf

9. A.M. Casado, J.I. Peláez, J. Cardona, Coporate Reputation Review, 17,1:4663(2014). https://link.springer.com/article/10.1057/crr.2013.23

10. R.B. Pradesta, Pengaruh etnosentrisme, brand image dan product knowledge terhadap keputusan pembelian produk pakaian jadi impor, [The influence of ethnocentrism, brand image and product knowledge on the decision to purchase imported apparel products]. [Undergraduate thesis], Faculty of Economics and Bussiness, Universitas Muhammadiyah Surakarta, 2014. [in Bahasa Indonesia]. http://eprints.ums.ac.id/30642/20/NASKAH_PUBLIKASI_ILMIAH.pdf

11. R.N. Manuarang, M.K. Mawardi, Jurnal Administrasi Bisnis, 55,3:41-47. [in Bahasa

Indonesia].http://administrasibisnis.studentjournal.ub.ac.id/index.php/jab/article/vi ew/2299 
12. A.R. Nugroho, (2015). Analisis pengaruh product knowledge, sikap pada produk terhadap minat beli produk Zandilac (Undergraduate thesis, Universitas Muhammadiyah Surakarta, 2015) [Online] from http://eprints.ums.ac.id/id/eprint/37085

13. L.G. Schiffman, L.W. Joseph, Consumer behaviour, Harlow: Pearson (2015). https://www.pearsonhighered.com/assets/preface/0/1/3/4/0134734823.pdf

14. E.M. Sangadji, M. Sopiah. Perilaku konsumen: Pendekatan praktis. [Consumer Behavior, Practical Approach]. Jakarta: Andi Publisher (2013). [in Bahasa Indonesia]. http://andipublisher.com/produk-0414005166-perilaku-konsumenpendekatan-praktis.html

15. H. Herwin, F. Abadi. Jurnal Riset Manajemen dan Bisnis (JRMB) Fakultas Ekonomi UNIAT, 3,3:353-364(2018). [in Bahasa Indonesia]. http://jrmb.ejournalfeuniat.net/index.php/JRMB/article/view/161

16. J. Kolonio, D. Soepeno, Jurnal EMBA, 7,1:831-84(2019). [in Bahasa Indonesia]. https://ejournal.unsrat.ac.id/index.php/emba/article/view/22910

17. C.J. Fombrun, N.A. Gardberg, J.M. Sever, The Journal of Brand Management, 7:241-255(2000). https://link.springer.com/article/10.1057/bm.2000.10

18. A. Pradipta, N. Farida, H.S. Nugraha, Jurnal Ilmu Administrasi Bisnis, 4,2:440461(2015). [in Bahasa Indonesia]. https://ejournal3.undip.ac.id/index.php/jiab/article/view/8339

19. R.M. Tarigan, Pengaruh citra merek dan reputasi perusahaan terhadap keputusan pembelian smartphone Samsung pada mahasiswa fakultas ekonomi dan bisnis universitas Sumatera Utara. [Influence of brand image and company reputation on the purchasing decision of Samsung smartphones in the faculty of economics and business at the university of North Sumatra]. [Undergraduate Thesis]. Fakultas Ekonomi dan Bisnis, Universitas Sumatera Utara, Medan, 2014. [in Bahasa Indonesia]. http://repository.usu.ac.id/handle/123456789/47768

20. C. Rosidah, The influence of corporate reputation and trust to consumer loyalty of ATM users after cybercrime isues (Study at BCA consumers in Surabaya). [Research paper], (2011). p. 1-18. [in Bahasa Indonesia]. [Online] from : https://www.scribd.com/doc/55903514/Reputasi-Perusahaan-dan-KepercayaanTerhadap-Loyalitas-Nasabah-Pengguna-ATM-Pasca-Isu-Cybercrime-Studi-padaNasabah-BCA-di-Surabaya

21. V. Simamora, C. Celeste, Jurnal Akuntansi Manajerial, 2,2:24-36(2017). [in Bahasa Indonesia]. http://journal.uta45jakarta.ac.id/index.php/JAM/user/setLocale/id_ID?source=\%2 Findex.php\%2FJAM\%2Farticle\%2Fview\%2F930

22. R. Rahmawati, Hubungan antara Reputasi Perusahaan dengan Kepercayaan pada Konsumen Ekspedisi X, [The Relationship Between Company Reputation and Trust in Consumer Expedition X] [Undergraduate thesis], Faculty of Psychology, Universitas Muhammadiyah Surakarta, 2017. [in Bahasa Indonesia]. http://eprints.ums.ac.id/58480/

23. M. Widodo, Jurnal Manajemen Update, 6,4:1-12(2017). [in Bahasa Indonesia]. http://jurnal.untan.ac.id/index.php/ejmfe/article/view/23456

24. R.F.P. Lubis, R.H. Magnadi, Dipenogoro Journal of Management, 4,4:1-10(2015). [in Bahasa Indonesia]. http://eprints.undip.ac.id/46781/

25. K.R. Limoputro, G. Waney, Jurnal Manajemen dan Start-Up Bisnis, 2,6:1-10 (2018). [in Bahasa Indonesia]. https://journal.uc.ac.id/index.php/performa/article/view/611 
26. A.N.T. Rondonuwu, Pengaruh pengetahuan produk terhadap kepercayaan dan niat beli calon pengguna Smartfren Andromax di Sidoarjo, [The influence of product knowledge on trust and purchase intentions of potential Smartfren Andromax users in Sidoarjo], [Undergraduate Thesis], Sekolah Tinggi Ilmu Ekonomi Perbanas Surabaya, 2014. [in Bahasa Indonesia]. http://eprints.perbanas.ac.id/2067/1/ARTIKEL\%20ILMIAH.pdf

27. C. Wang, C. Chen, J. Jiang, Journal of Computers, 4,1:11-18(2009). http://citeseerx.ist.psu.edu/viewdoc/download?doi=10.1.1.415.9541\&rep=rep1\&ty pe $=$ pdf

28. R. Kusumah, Jurnal Berkala Ilmiah Efisiensi, 5,15:355-366(2015). [in Bahasa Indonesia]. https://pdfs.semanticscholar.org/7b2b/8af422d684d4851f3244831da8ac8fb17436. pdf? ga=2.9605494.299141506.1580256961-1770140902.1580256961

29. A.Y. Satrio, Lindawati, D. Kamener, Jurnal Manajemen Fakultas Ekonomi Universitas Bung Hatta, 6,2:1-14(2015). [in Bahasa Indonesia]. http://www.ejurnal.bunghatta.ac.id/index.php?journal=JFEK\&page=article\&op $=v i$ ewFile\&path[] $=4355 \&$ path []$=3679$

30. A.E. Kusumawardani, Pengaruh kepercayaan terhadap keputusan pembelian online shop: Studi kuantitatif di kalangan siswi kelas XI IPS 3 SMA Negeri 4 Surakarta melalui online shop di instagram, [Influence of confidence in online shop decision making: Quantitative study among students of class XI IPS 3 SMA Negeri 4 Surakarta through online shop on Instagram]. [Undergraduate thesis], Universitas Muhammadiyah Surakarta, 2017. [in Bahasa Indonesia]. http://eprints.ums.ac.id/id/eprint/55273

31. Rosidah, Jurnal Pendidikan Tata Niaga, 3,3:1-9(2016). [in Bahasa Indonesia]. https://jurnalmahasiswa.unesa.ac.id/index.php/jptn/article/view/16321

32. Ghozali, Structural Equation Modeling, Metode Alternatif dengan Partial Least Square (PLS), [Structural Equation Modeling, Metode Alternatif dengan Partial Least Square (PLS).], Semarang: Badan Penerbit Universitas Diponegoro (2014). [in Bahasa Indonesia]. https://digilib.undip.ac.id/v2/2012/10/04/structuralequation-modeling-metode-alternatif-dengan-partial-least-square/

33. R.D. Pangesti, I.M. Sumertajaya, A. Sukmawati, Partial Least Square Structural Equation Modeling (Pls-Sem) Pada Data Biner, (Kasus: Faktor Pendorong Peningkatan Pengetahuan Koperasi Susu Di Indonesia). [Partial Least Square Structural Equation Modeling (Pls-Sem) in Binary Data (Case: A Driving Factor for Increasing Knowledge of Dairy Cooperatives in Indonesia)], [Theses], MT, Institut Pertanian Bogor, 2016. [in Bahasa Indonesia]. https://repository.ipb.ac.id/handle/123456789/82687 